\title{
Pangastuti Dance: The Acculturation of Balinese and Yogyakartan Cultures
}

\author{
Ni Nyoman Seriati ${ }^{1, *}$ \\ ${ }^{1}$ Faculty of Languages and Art, Yogyakarta State University, Yogyakarta, Indonesia \\ ${ }^{*}$ Corresponding author.Email:ni_nyomanseriati@uny.ac.id
}

\begin{abstract}
The phenomenon of cultural acculturation in Indonesia grows rapidly. This is caused by the migration of the population from one to another area, including the Balinese people who spread to various parts of the country in Indonesia. The phenomenon of cultural acculturation through art, especially dance can be studied through a Pangastusi dance. The aim of this study is to describe the Pangastusi dance ethnographically, so that the background, and aspects of its constituent elements can be elaborated. The data in this study were collected through observations on Pangastuti dance videos. This was done to find the variety of movements, costumes, and music of the female Yogyakartan style in the Pangastuti dance performance. The data found in the Pangastuti dance were analyzed, and described. Also, the position of movement, costume, and music that exists in the dance were interpreted. Verbal descriptions were used in analyzing the data. The results of the study show that there are ten types of Yogyakartan-style dance movements used in the Pangastuti dance, including the movements of lembeyan, kenser, trisik, ombak banyu, gajah ngoling, seblak sampur, tumpang tali, jengkeng jeblosan, and ngelayang. Then, the costume and accessories include pending, centung, gelangkono naga, sari ayu, pelik, untaian melati, and gelung bokor. In addition, the music covers gending kemanak used in the presentation (sembahan) and at the end (pakaad) of the Pangastuti dance.
\end{abstract}

Keywords: acculturation, movements, costume, music

\section{INTRODUCTION}

Pangastuti Dance is a new creation by Ni Kadek Rai Astini. It was created in 2012 for the Hindu Religious Art Festival. The dance is a result of acculturation between the dance styles of Yogyakarta and Bali. The acculturation of these two cultures has begun since the 1950's when the Balinese migrated to Yogyakarta. As one of the ways to show their existence among the locals, the Balinese brought their culture and art to perform in college campuses and other places.

As a cultural element, dance is an inseperable part that instrumental to human life as it exists in nearly all cultures of humankind. This also applies to the Balinese people in Yogyakarta who uses art as an effort to integrate into the Yogyakarta communities.

In addition, the presence of art becomes essential as it serves as a characteristic to show their identity as a minority. Art and cultural activities are important to show and strengthen cultural identity of a social group. Dances, plays, traditional music, and other forms art serve to communicate an individual's identity and imitate the identity of other groups. The migration of the Balinese to Yogyakarta in a long range of time links to each other and influences both the local and the new culture. Koentjaraningrat (1987 p. 110) states that the acculturation which happens in the Pangastuti dance, with the incorporation of movement, costume, and gending kemanak (as the music accompaniment) is not merely an accesory, as there is a substantial influence affecting the two cultures. This integration may not be obvious, but the new

atmosphere will be present and felt as the essence of acculturation is change. The essence of the change signifies the Sedyawati art tradition $(1975$, p. 89$)$.

On certain occasions, creative collaboration is done with each other so that it eventually diversifies the development of dance as a performance art by the Balinese artists in Yogyakarta. Additionally, the cultural dialogues done between the artists, whether in the academic or non-academic context, may influence the result of the creative collaboration by these artists. The openness between one another provides an opportunity for acculturation in the art development of both cultures to occur, for instance, in the new dance works, traditional music such as karawitan, visual art, and other forms of arts of the Balinese artists in Yogyakarta.

Based on the above notions, this study aims to study the acculturation of the Yogyakarta-style dance tradition in the creation process of Pangastuti dance by Ni Kadek Rai Astini. This study focuses on three elements, namely movement, costume, and music accompaniment.

\section{METHOD}

This is a qualitative descriptive study. According to Sugiyono (2012, p. 17) a qualitative study views an object as a dynamic thing, as well as the result of a thought construction and whole interpretation. Every aspect from the object must have a united entity which cannot be separated from each other. This study was conducted to explain the phenomena that occurred on the research object and describe the acculturation process of the Yogyakarta-style movements of the Pangastuti dance. The research object in this study was the Pangastuti 
dance which was created by Ni Kadek Rai Astini in 2012. The study was focused on the movement, costume, and music accompaniment.

Data collection was done through meticulous observation on the Pangastuti dance through a video medium to obtain the main research data, as well as photographs, to gain the secondary data. The scope of the study involved the movement, costume, and music in the work. The results of the observations on the video and photographs were noted in detail based on the research needs. The data analysis used the Miles and Huberman method in Sugiyono (2011, p. 337), which was conducted in three stages, involving data reduction, data display, and drawing conclusions.

\section{DISCUSSION}

\subsection{Background of the Pangastuti Dance}

The Pangastuti dance was created in 2012 by Ni Kadek Rai Astini, M.Sn. This dance was performed for the National Hindu Religious Ritual Festival which was held by the Directorate General of the Hindu Religion of Indonesia. The Pangastuti dance is a representative of the Hindu people in Yogyakarta Special Region, which consists of a mixture of the natives of Yogyakarta (Javanese), as well as the Balinese that reside in Yogyakarta. These two origins are what ultimately affect the Pangastuti dance, as it is resulted from the acculturation of two cultures.

This dance is performed by six female dancers with a property of pasepan which contains an incense. This property serves to provide a magical atmosphere which suits the religious theme. The dancers use identical costumes, with a white and yellow base as the main colors, which are commonly used for ritual dances. The music accompaniment includes a set of gong kebyar gamelan which utilizes the Balinese technique of producing a dynamic sound. On the other hand, the gending work applies the common composition for Yogyakarta-style dance. The structure of the dance performance is as follows: pengawit (the beginning), pengawak (the development of the body and hands flexibility), pengecet (quick movements), and pakaad (the ending).

\subsection{The Acculturation of Yogyakarta-Style Dance in the Pangastuti Dance}

The study conducted on the Pangastuti dance are focused on the movement, costume, and music. The results are as follows.

\subsubsection{Movement}

As the main element in a dance work or performance, the movement of the dancer serve to communicate the meaning of the dance to the audience. Some of the movements developed from the Yogyakarta-style dance for the Pangastuti dance includes kenser, lembeyan, ombak banyu, nggoling, tumpang tali Seblak sampur jengkeng jeblosan nglayang sembahan, and trisik. In addition, the movements adapted from the Balinese dance are agem seledet, ngitir, nyeleog ngegol ngelikas ngelung nyalud, manganjali miles, and nyogok.

These two styles of movements are acculturated with one another in Pangastuti dance. For instance, the trisik and kenser are combined with ngelung. The integration of the two styles of movement generate a new movement in which the hand work is ngelung, while the foot work is kenser/trisik. Next, the lembeyan is combined with nyelikas as they have similarities in the sway of the body and the hands. When combined, the two movements work harmoniously with no dominating movement as the body uses the nyelikas movement and the hands follow the lembeyan.

Another movement form called seblak sampur (Yogyakarta) is combined with the nyeleog (Bali) movement due to their similarities in the flexibilities of the hands and body movement, creating one harmonious motion.

In the ending, sembahan movement is combined with the foot position of jengkeng jeblosan, followed by the nglayang movement. These movements are combined with manganjali, which is the religious hand gesture of the Hindu people to pray, that is with two fingers facing up. The direction of the fingers is aimed at the God Almighty (Hyang Widi Wasa). Meanwhile, in a Yogyakarta-style classical dance, the fingers up are directed forward to give respect to the king. The combination of the movements above can be seen below.

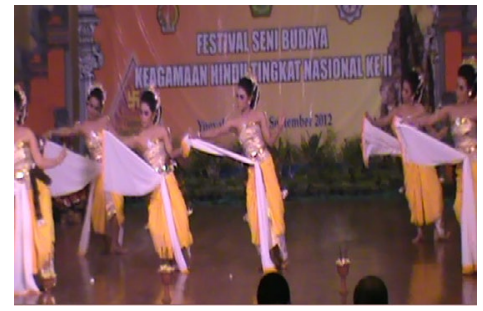

Figure 1. Combination of trisik

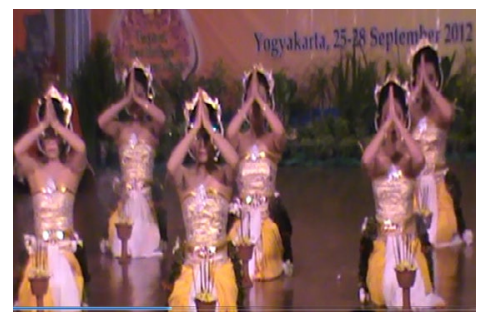

Figure 2. Sembahan and ngelung

The acculturation of both cultures works harmoniously due to the similarities between the basic positions of both of the dance styles. The basic body stance (adeg-adeg) in Balinese dance involves four body parts, namely the position of the feet, body, hands and the head. The body stance in female dance requires more cengked [1]. Dibia $(2013$, p. 37) points out that to perform the Yogyakarta-style dance well, one must have a strong body stance, involving good posture (adeg), pasemon and eye direction, neck movement, hand and wrist position, as well as the foot position and movement [8]. 
From the descriptions above, it can be stated that the two dance styles have the same requirements to perform, whether the posture or stance or the movement technique. Similarities also exist in the aesthetical elements of the dance styles. Whereas Yogyakarta has wiraga, wirama, and wirasa, the terms are known as agem, tandang, and tangkep in Bali. The similarities among the two concepts are as follows: Wiraga relates to the posture or stance that is similar to that in Balinese dance; wirama concerns with the rhythm of movement and music, while tandang in Balinese dance is known as the ability to master movements with music; finally, wirasa is associated with the process of immersing into the character or role, which in Bali is known as tangkep, pinjiwaan or expressions. Among the three elements in each style, although the applications may not be entirely identical, there is a general outline in the technical and immersion achievements.

Specifically, the dancer's immersion process into the role or character in Yogyakarta style dance is known as Ilmu Joged Mataram, consisting of sawiji, greged, sengguh, and ora mingkuh. Sawiji refers to the alignment of the intent and attitude with the entire spiritual energy and mind on a clear objective depending on the role and character. Greget is the strong willingness that pushes certain dynamics in the soul of the dancer, but still under control. Sengguh is selfconfidence in which there is no distance, not arrogance. Ora mingkuh can be defined as resilient and responsible [8]. It is also emphasized that the dancer must focus their mind on one intent, that is to dance as well as they can within their limitations and use their potential [9]. There are two crucial things for dancers to be able to perform a classical Yogyakarta-style dance, that is understanding the philosophical foundation as well as the skills and the inner and outer techniques [8]. According to B.P.H. Suryobrongto (1970, pp. 10-11) Yogyakarta style dance is the technique, while Joged Mataram serves as the substance or the soul [7]. In regard to that, the immersion process also exists in Balinese dance and often referred to as taksu, which is a magical power from God which determines the beauty of the dance performance. As a spiritual power, taksu enters the dancer when she expresses herself on the stage. A dancer is considered to have possessed taksu when she can fully transform herself perfectly based on her role in the dance [2]. In addition to taksu, Dibia states that a power which can build harmony or alignment for the dancer is called pangus, i.e. the ability or success of a dancer in delivering the role or character in the performance on stage [1]. Dibia $(2017$, p. 24) adds that because of this, taksu and pangus are instrumental in the beauty of Balinese dance. While taksu is more spiritual, pangus serves as the physical counterpart.

Based on the description above, it can be concluded that the two styles of dance have several similarities in the aesthetic elements that the dancers must possess, whether in terms of the technique or the essence. These aesthetic elements allow for the acculturation of movements in Pangastuti dance to occur organically. None of the movements seem forced as they complement each other and are considered to be a new breath of style. The integration of movements in the new dance work is a result of acculturation of various traditional dance movements in the country. Therefore, the dance is perceived as a new work that can be appreciated by the audience. Dibia noted that artists have done various innovations by incorporating new ideas in traditional dances without abandoning the artistic values and aesthetic principles of the original traditional art [1]. Hidayat adds that each dance work is an accumulation of several movements developed from the existing dances, such as the classical and folk dances [3].

\subsubsection{Costume and Accessory in Pangastuti Dance}

To the audience, costume is the most visible part of the dance performance which can show the identity of the dance or where it comes from. In addition to showing the regional identity, costumes are also important to show the character that the dancer plays based on the colors that serve to represent certain ideas or concepts.

The colors of the Pangastuti dance costume are yellow and white, which represents greatness and purity, respectively. These colors are typically identical with the characters of begawan, pendeta, wali, and other characters of high level of spirituality. Harymawan (1993, pp. 131-132) points out that costumes are used to help make the characters come to life, as well as providing means and facilitating the dancer's movements [10].

The costume of the Pangastuti dance attempt to preserve the tradition of the two cultures. The Yogyakarta style costume consists of sampur polos, pending gelang kono naga, gelung bokor, untaian melati, pelik, sari ayu, centung, and buntal from the Yogyakarta style, while the Balinese dance includes sabuk (stagen) prada, kamen (fabric) prade, and a torso wrap. In Pangastuti dance, the accessories around the head are from the Yogyakarta style, while the Balinese elements are used in the body, such as kamen (kain prada) and sabuk (kamen prada).

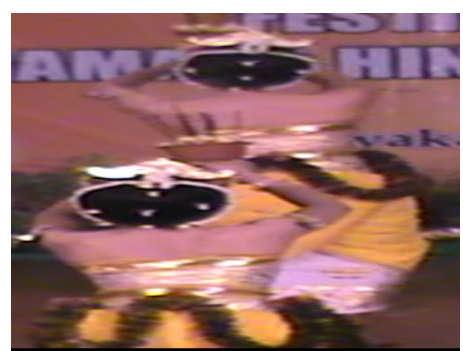

Figure 3. The front and back views of the costume

\subsubsection{Music Accompaniment in Pangastuti Dance}

Music is an important element in a dance performance both in Java and Bali, although some traditional dance styles such as the Saman and Kecak dances do not need any music (gamelan). There are three patterns of interaction between the dance and the music in Bali, namely: the music following the dance (tabuh nuut igel), the dance following the music (igel 
nuut tabuh), and a combination of both where music and dance secara bergantian saling mengikuti (tabuh lawan igel saling nuwutin). Dibia (2013, p. 127) states that the notions on music accompaniment show how in the Balinese tradition, music sets the soul and the tone of the dance, serves to accentuate the dance (angsel-angsel), as well as frames each movement performed by the dancer.

Meanwhile, in the Yogyakarta-style dance, the harmony between the rhythm of the motion and that of the gending as the music accompaniment is based on the the beat of the gong, kenong, kempul, and ketuk (Wibowo, 2002, p. 46). It is also pointed out that a dancer must have three kinds of sensitivity, namely: the sensitivity of the gending rhythm, the sensitivity of the rhythm of the motion, and distance rhythm sensitivity. The sensitivity of gending rhythm and feeling is important to follow the rhythm of gending accurately based on the gong, kenong, kempul, and ketuk. The sensitivity to the motion rhythm refers to how a dancer moves her body in a steady tempo (ajeg), to produce a series of movements that flows. Finally, the sensitivity of distance rhythm determines the dancer's ability to consider the distance and move in regard to the motions of the body.

The gending accompaniment music consists of various traditional instruments such as saron, demung, peking, kendang, kenong, gong, kempul, bonang, rebab, siter, and others from Yogyakarta, while the Balinese instruments include kendang, cengceng, reyong, gangse, ugal, pemade, kantil, jublag, jegogan, gong, kenong, kempul, and kajar. The musical instruments from the two regions have slightly different forms and ways of playing, but the types of instrument are essentially similar though not identical. Both of these regions use laras pelog and selendro.

Based on the similarities of the two regions as described above, the use of the gending kemanak (Yogyakarta style) in the Pangastuti dance work produce a more integrated result. This gending is used as a music accompaniment for the prayer section in the middle and end of the performance. The acculturation in the Pangastuti dance is a result of the similarities of the musical instruments, how they are played, as well as the laras (traditional musical pattern) used. The similarities in cultural elements allow the different cultures to influence each other.

\section{CONCLUSION}

Similarities are found in the three elements that are studied in this research, namely the movement, costume, and music. The similarities exist in the aesthetic elements of wiraga, wirama, wirasa (Yogyakarta) and agem, tandang, and tangkep in Bali. Both of the dance style also required dancers to master the posture or body stance, as well as the music and immersion process (expression).

Therefore, it can be assumed that the similarities between the cultures have influenced each other. Instead of eliminating the character of the dance, the acculturation of Pangastuti dance manages to integrate the movements of two dance styles in the body, hands, ahead, and feet movements. The costume, accessories, and music elements also work together well and organically without any enforcement. The unification of the two styles results in a new style of dance, namely the Pangastuti dance.

\section{REFERENCES}

[1] Dibia, I. Wayan. 2013. Puspasari Seni Tari Bali [Puspasari of Balinese Dance Arts]. Institut Seni Indonesia Denpasar, UPT Penerbitan

[2] Dibia, I Wayan. 2012. Taksu dalam Seni dan Kehidupan Bali [Taksu in the Balinese Art and Life]. Denpasar: Bali Mangsi.

[3] Hidayat, Robby. "Koreografi dan

Kreatifitas." Yogyakarta: Kendil Media Pustaka Seni

Indonesia["Choreography \& Creativity Knowledge and Choreography Practicum Instructions]." (2011).

[4] Koentjaraningrat. Sejarah Teori Antropologi I [History of Anthropology Theory I]. Jakarta: UI Press, 1987.

[5] Sugiyono. 2011. Metode Penelitian Pendidikan, Pendekatan Kuantitatif, Kualitatif, dan R \& D

[Educational Research Methods, Quantitative Methods, Qualitative, and R\&D]. Bandung: Alfabeta.

[6] Sedyawati, Edi. 1981. "Pertumbuhan Seni Pertunjukkan [The Growth of Performing Arts], Jakarta : Sinar Harapan.

[7] Suryobrongto, B.P.H. Ceramah Tentang Tari Klasik Gaya Yogyakarta [A Lecture about Yogyakarta Classical Dance]. Yogyakarta: Museum Kraton Yogyakarta. 1976.

[8] Wibowo, Fred. Tari klasik gaya Yogyakarta [Yogyakarta-style classical dance]. Yayasan Bentang Budaya, 2002.

[9] Beksa, Dewan Ahli Yayasan Siswa Among, and Ngayogyakarta Hadiningrat. "Kawruh Joged Mataram [Knowledge of Mataram Dance]." Yogyakarta: Yayasan Siswa Among Beksa (1981).

[10] Harymawan, RMA. Dramaturgi. Bandung: PT Remaja Rosdakarya. 1993 